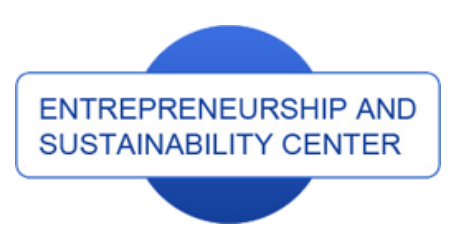

Publisher

http://jssidoi.org/esc/home enterprise

europe

network

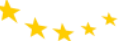

Business Support on Your Doorstep

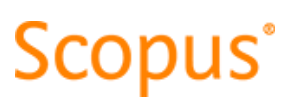

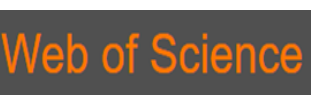

Clarivate
Analytics

\title{
SECURITY OF THE BUSINESS ORGANIZATIONS AS A RESULT OF THE ECONOMIC CRISIS*
}

\author{
Nadežda Jankelová ${ }^{\text {, Andrea Jankurová }}{ }^{2}$, Martina Beňová ${ }^{3}$, Zuzana Skorková ${ }^{4}$ \\ 1,3,4 University of Economics, Slovakia; ${ }^{2}$ Danubius University, Sládkovičovo, Slovakia \\ E-mails: ${ }^{1}$ nadezda.jankelova@euba.sk; ${ }^{2}$ andrea.jankurova@vsdanubius.sk; ${ }^{3}$ martina.benova@euba.sk; \\ zuzana.skorkova@euba.sk
}

Received 10 December 2017; accepted 15 March 2018; published 30 March 2018

\begin{abstract}
Global economic crisis is one of the most significant environmental changes influencing all managerial functions - including entrepreneurs and organization. In this paper, we study how entrepreneurs used organization to deal with the security and sustainability issues stemming from the global economic crisis. Crisis forced managers to undertake various organizational changes that led to a sharp reduction in the number of employees and thus flat organizational structure are the trend among structures. Organization is focused more on designing. One of the newest and fastest growing business trends is the creation of networks and clusters. We conducted research on a sample of 115 foreign and domestic companies running their business in Slovak Republic. We were interested in the perception of lean management, project management and strategic alliances creation during the crisis and in nowadays. We provided an analysis of changes in span of management and managerial level reduction. To analyse the companies, we used descriptive and inductive statistical methods on the lowest possible significance level. Based on our research we found that the optimization of the organizational structure can be the way for helping business companies to overcome economic insecurity in the times of the crisis.
\end{abstract}

Keywords: organization, entrepreneurship, economic crisis, security, organizational structure, sustainability, lean management, Slovakia

Reference to this paper should be made as follows: Jankelová, N.; Jankurová, A.; Beňová, M.; Skorková Z. 2018. Security of the business organizations as a result of the economic crisis, Entrepreneurship and Sustainability Issues 5(3): 659-671. http://doi.org/10.9770/jesi.2018.5.3(18)

\footnotetext{
* This research was supported by the project „, The innovative approaches to management and their influence on the competitiveness and the successfulness of the companies within the conditions of the global economy. ", VEGA No.: 1/0109/17 - a project funded by the University of Economics in Bratislava and led by doc. Ing. Nadežda Jankelová, Ph.D.
} 


\section{Introduction}

Theory and practice are currently based on years of proven and widely used system framework that divides the structure of management into several basic functions. In the theory of modern management, the division into functions are following - planning, organization, decision making, personnel management, leadership and control. This basic or detailed breakdown is very useful because it offers a solid structure in which new insights can easily be incorporated. The content of features is constantly evolving and responding to changing environmental conditions. One of them is also the crisis which is a milestone, the sudden disruption of the way the business operates. Economic crisis, recession, stagnation, decline - these are the concepts that are still discussed in the mass media, while at the same time they are raising the reflections, concerns over the future. The economic crisis has brought a large number of businesses into difficult situations which have resulted in their fundamental or existing changes in their current functioning. Changes made can also be seen in management functions. The misconception of overcoming the economic crisis lies not only in reducing costs, increasing efficiency and productivity. It is necessary to focus on the future, to better estimate the situation, not to stay in the "wait-and-see strategy", to predict ahead of schedule, to make more effective and more targeted decisions, to provide motivating incentives to employees, to more persistently influence the attitudes of the subordinates, to change the way of managing the company in the long- new management methods that require multiple forms of knowledge acquisition, educational activities, and so on.

In addition to the negative consequences, the economic crisis also presents new challenges, impulses, the need for new solutions and changes in the functions themselves (Abrham et al., 2015). After studying the foreign and domestic scientific and professional literature, we have met a number of analyses and assessments of the impact of the global economic crisis on various macroeconomic indicators. To a very limited extent, these studies addressed issues related to impacts on the management process. This research is largely absent. That is why we have focused on the research of changes in managerial functions that were caused by crisis. In our paper we present the research results in the field of changes in organization that were caused by crisis. We aimed the research on following specific concepts - perception of lean management from the perspective of companies operating in Slovakia. Another concept we paid attention to in the survey was the usage of project management. The third concept we were focused on was the strategic partnerships creation. As a result of personnel effect conditioned by the crisis, the organizational area has seen changes in organizational structure. Organizational structures tended to be slimmed due to letting go of work force. This trend is visible in delayering and other changes in organizational structure that were done to increase the efficiency of business operation.

\section{Literature review}

Organization during the crisis as well as post-crisis period is an inseparable part of managerial work. According to Hamel, building an organization that is as flexible as much as it is effective is probably one of the most fundamental challenges facing businesses today. Hamel (2006) is of the opinion that the majority of current systems and approaches to management are based on an outdated management principle. For the companies to prosper again in a business environment marked by the consequences of the economic crisis, changes made, and new situations, they must organize less and free the level of management, structuring, hierarchy, and routines. Organizations based on an ideology that preventively and structurally gives power to the minority and takes it away from the majority will have no chance of success in the future. (Grant, 2008) 


\section{The International Journal \\ ENTREPRENEURSHIP AND SUSTAINABILITY ISSUES}

ISSN 2345-0282 (online) http://jssidoi.org/jesi/

2018 Volume 5 Number 3 (March)

http://doi.org/10.9770/jesi.2018.5.3(18)

The economic crisis underlined in specific managerial positions the importance of human resources in the sense of greater engagement in planning, decision-making, creating organizational values, and also in the decentralization of powers (Holagh et al., 2014).

During the economic recession, many managers were forced to undertake various organizational changes that led to a sharp reduction in the number of work forces. Due to decreasing number of employees, organizational structures have been optimized (sliming or flattening) in a natural way. Today, companies are operating with fewer management levels and by delegating greater powers to individual workers. The condition of success of each company is adequate and flexibly corresponding organizational structure. Traditional forms of organizational structures are abandoned with more modern structures coming to the foreground that are marked with strong employee engagement and power authority is transforming into authority based on expertise and knowledge. New organizational structures are linked to new responsibilities, competences, actual work, and systems for measuring system and employee performance (Simionescu et al., 2016). Flat organizational structures are a trend among structures (Morgan, 2015; Kastelle, 2013; Janda et al., 2013). A benefit of these structures is especially the adoption of quicker decisions, improving quality and speed of information sharing, strengthening of horizontal communication between employees and a small number of management levels (Nigro et all, 2006; Qi et all, 2014). Organization is focused more on designing (Záležáková, 2012). It is important for the companies to be able to design projects, because current business environment is characterized by greater uncertainty, frequent changes, post-crisis development that reflected in the emergence of new, thus far unresolved issues and tasks. As a reaction to difficult conditions and new challenges, new projects are emerging and, understandable, the importance of project management (Pinto and Winch, 2016), project organizational structures, and structures based on teamwork is growing. Zagorsek et al. (2017) identified a positive impact of project management and project orientation on competitiveness of a modern company. They also found a relationship between success and companies focused on low financial and material demands. Tarišková (2015) describes the need for the application of balanced scorecards in project management. Mišún and Mišúnová (2017) identified the relationship between organizational structure and control.

Reducing hierarchical structures and redundant management levels prompted interest in the concept of leaning Lean management. Lean management is nothing new in our conditions and it helped many companies to improve performance almost to the world level (Trend, 2016). According to several experts (Burton - Boeder, 2003) (Charron et all, 2015) (Košturiak, 2012) (Georgescu, 2011; Sabic-Lipovaca et al., 2016) the era of worldwide slimming has arrived (for example) in the area of manufacturing (Vilkas et all, 2015), logistics (Jirsák and Holman, 2012; Krejcí et al., 2015), development (Košturiak, 2012), administration (Košturiak, 2012), thinking (So and Sun, 2015), processes (Tenera and Pinto, 2014), or job satisfaction (Čábelková et al. 2015a; Čábelková et al. 2015b). The implementation of lean management requires an interdisciplinary approach, but also a lot of patience (based on Trend analyses (2016) 70\% of attempts fails according to conducted global analyses) - it is a long-term culture of constant self-improvement. During the economic recession, companies became more aware of the fact that they cannot afford unnecessary costs in the form of surplus stock, surplus production, or various manufacturing deficiencies, e.g. reduced quality or possible complaints. Because of these and other reasons, companies sought optimization, rationalization and slimming of oversized processes and activities, i.e. eliminating everything that did not bring value to the company with the goal of streamlining processes and reducing costs to the minimum level. We are also witnesses of the creation of Lean Six Sigma (Pamfilie et all, 2012), which is the synthesis of Lean Management and Six Sigma (Dekier, 2012; Tenera and Pinto, 2014). Both methodologies complement each other in order to improve quality, performance, and satisfaction of customers under reducing costs.

Various strategic partnerships are becoming a trend today. The main themes of strategic cooperation are mainly the consequences of the global economic crisis for management and changing economic environment offering 
The International Journal

ENTREPRENEURSHIP AND SUSTAINABILITY ISSUES

ISSN 2345-0282 (online) http://jssidoi.org/jesi/

2018 Volume 5 Number 3 (March)

http://doi.org/10.9770/jesi.2018.5.3(18)

new, more complex challenges. During the economic crisis the companies were searching for new ways how to gain or maintain a competitive advantage. An alternative to addressing the negative consequences of the crisis was the support for creating networks and clusters. The creation of networks and clusters is currently one of the newest and fastest growing business trends. Business networks and clusters are tools, using which companies can resist the adverse impact of the economic crisis and to resume business based on mutual interdependence and cooperation of the clustered entities (Beňová and Szabo, 2016; Razminiené, Tvaronavičienè, 2017; Monni et al., 2017). Other options for eliminating the effects of the recession were to create fusions and acquisitions.

\section{Methodology and empirical model}

To obtain the desired results we have used the empirical method of observation using a questionnaire survey. The questionnaire was distributed by electronic communication at the beginning of October 2016, whereby data collection was completed in February 2017. 117 questionnaires have been included in the research sample, of which 2 did not meet the relevant completeness, due to which they were not included in the survey. The total number of distributed questionnaires was 370 and the return rate was $31 \%$. Targeted segment of our research was randomly chosen Slovak and foreign enterprises running their business in Slovak republic whereby respondents were members of higher management. Inductively-deductive methods, descriptive methods and Pearson's correlation coefficient were used to analyze collected data. We considered a result to be statistically significant at a significance level of $\mathrm{p}<0.05$.

Authors of many foreign scientific articles described the crisis and post-crisis period as the world-wide slimming era. Companies sought optimization, slimming of oversized processes and activities for the purpose of minimizing surplus costs. We were interested in the perception of lean management from the perspective of companies operating in Slovakia, and therefore given concept became part of our survey.

Table 1. Organization in crisis and in nowadays

\begin{tabular}{|c|c|c|c|c|c|}
\hline & \multicolumn{4}{|c|}{ Assessment level } & \multirow[b]{3}{*}{$\sum$} \\
\hline & 1 & 2 & 3 & 4 & \\
\hline & \multicolumn{4}{|c|}{ Number of companies } & \\
\hline During the crisis the lean management was applied. & 29 & 26 & 36 & 24 & 115 \\
\hline \multirow{2}{*}{ Lean management is applied in current period. } & \multicolumn{2}{|l|}{ No } & \multicolumn{2}{|c|}{ Yes } & \\
\hline & \multicolumn{2}{|l|}{51} & \multicolumn{2}{|c|}{64} & 115 \\
\hline During the crisis we applied more the project management. & 23 & 15 & 54 & 23 & 115 \\
\hline \multirow[t]{2}{*}{ Actually the concept of project management is applied. } & \multicolumn{2}{|l|}{ No } & \multicolumn{2}{|c|}{ Yes } & \\
\hline & \multicolumn{2}{|l|}{40} & \multicolumn{2}{|c|}{75} & 115 \\
\hline During the crisis we applied various forms of strategic alliances. & 69 & 26 & 15 & 5 & 115 \\
\hline \multirow[t]{2}{*}{ Actually we apply various forms of strategic alliances. } & \multicolumn{2}{|l|}{ No } & \multicolumn{2}{|c|}{ Yes } & \\
\hline & \multicolumn{2}{|l|}{85} & \multicolumn{2}{|c|}{30} & 115 \\
\hline
\end{tabular}

Note: totally disagree, 2 - partially disagree, 3 - partially agree, 4 -totally agree. Source: Own results

Of the aggregated data - see table 1, only 24 companies expressed their full approval that they implemented given concept during the crisis. Determined numbers do not have to necessarily suggest the actual situation. It happens that companies oftentimes do not know the management terminology and that they are using this type of management without even realizing the existence of the concept. Of the companies that inclined to lean management, large companies had the greatest share. It was ambiguous to identify in which management areas did the companies implement lean management, since these are very balanced results, see Figure 1. 


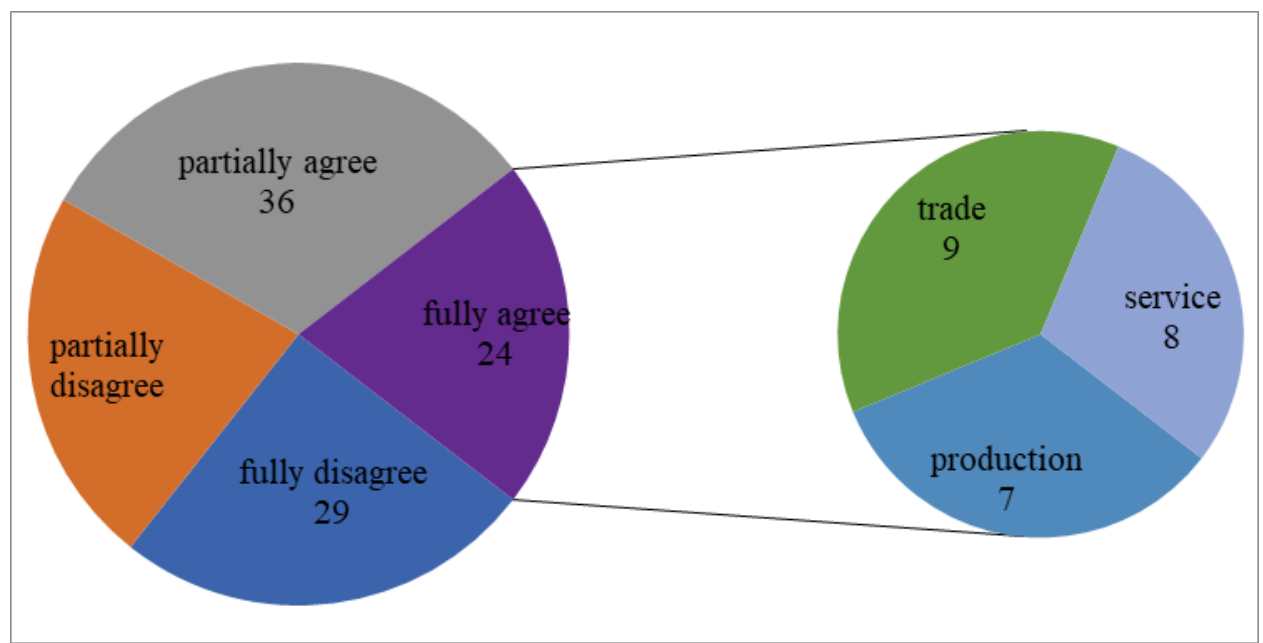

Fig. 1. Lean management in sectors

Source: Own results

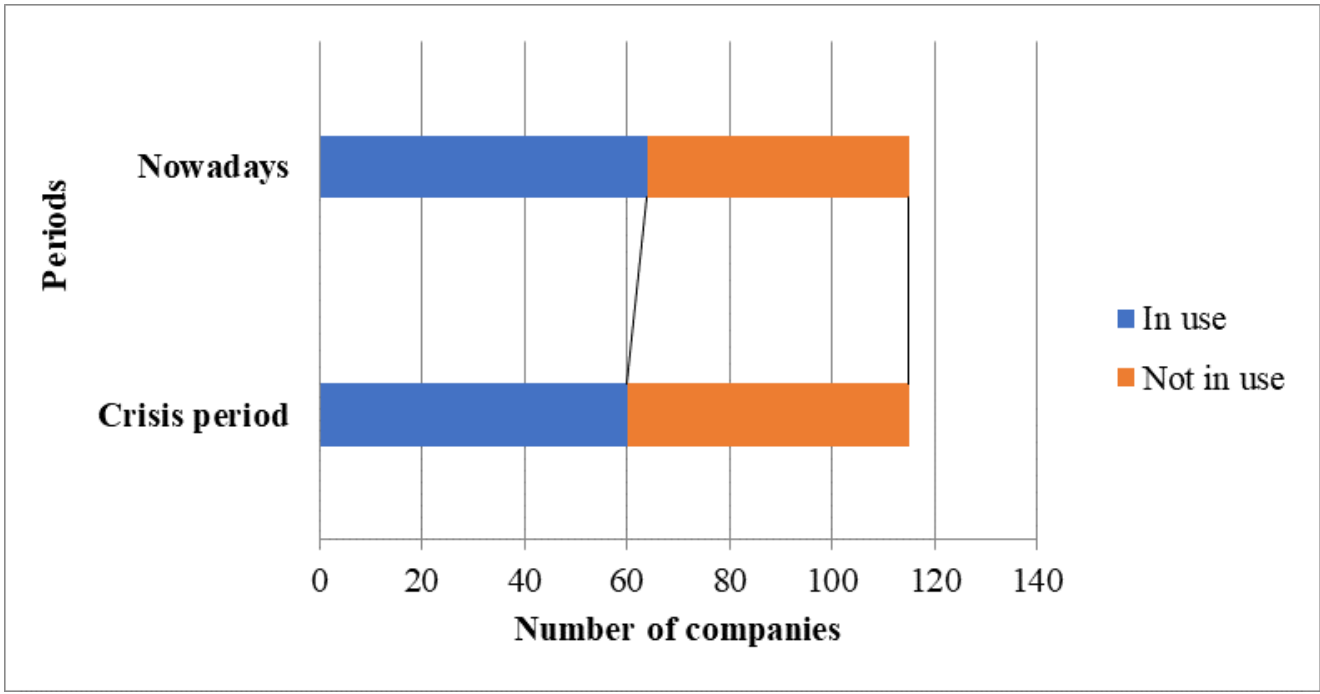

Fig 2. Interest in lean management during crisis and present

Source: Own compilation

Based on comparing the data from the crisis and post-crisis period it can be said that currently more than a half of the respondents (64/115) are using the concept and compared to the crisis period we observe a $6.67 \%$ increase (Figure 2). In order not to remain on an unconfirmed assumption that crises increase interest in lean management among companies, we decided to verify it statistically.

In the contingency Table 2 we compare 2 classification characters $\mathrm{A}$ and $\mathrm{B}$, where:

$-\mathrm{a}_{1}, \mathrm{a}_{2}$ are the observed periods, in our case the crisis period and the present,

- $b_{1}, b_{2}, b_{3}$ and $b_{4}$ are grades, where 1 - totally disagree, 2 - partly disagree, 3 - partly agree, 4 - totally agree. 
Table 2. Testing the dependencies between the periods and the level of lean management use

\begin{tabular}{|c|c|c|c|c|c|c|c|}
\hline & $\mathbf{b}_{1}$ & $\mathbf{b}_{2}$ & $\mathbf{b}_{3}$ & $\mathbf{b}_{4}$ & $\sum$ & \multicolumn{2}{|c|}{ Critical value } \\
\cline { 1 - 6 } $\mathbf{a}_{1}$ & 10,70 & 2,07 & 4,01 & 6,96 & 23,74 & \multicolumn{2}{|}{} \\
\cline { 1 - 6 } $\mathbf{a}_{2}$ & 13,42 & 2,59 & 5,03 & 8,74 & 29,79 & & $\mathbf{7 , 8 1 5}$ \\
\hline$\sum$ & 24,12 & 4,66 & 9,05 & 15,70 & $\mathbf{5 3 , 5 3}$ & $>$ & \\
\hline
\end{tabular}

Source: Own results

We compared the calculated testing characteristic with 95. percentile $\chi^{2}$ of the division with $(\mathrm{r}-1) .(\mathrm{s}-1) \cdot \chi^{2} 0.95$ (3) $=7.815$. Since the square contingency (53.53) exceeds the critical value, we can state that there is significant dependence between the crisis and the post-crisis period in using lean management. The intensity of eliminating any losses and waste in companies is actually affected by the economic crisis.

We used the Pearson's correlation coefficient to assess the contingency intensity rate, in the form:

$$
C=\sqrt{\frac{\chi^{2}}{\mathrm{n}+\chi^{2}}}
$$

By using the Pearson's correlation coefficient, we found a moderate dependence between the analysed periods (crisis and post-crisis) and the degree of using lean management. See Table 3.

Table 3. Dependence in Pearson's correlation coefficient

\begin{tabular}{|c|c|}
\hline Coefficient used & Value \\
\hline Pearson's correlation coefficient & 0,5636 \\
\hline
\end{tabular}

Source: Own results

Another concept we paid attention to in the survey was project management. According to some authors, organizing becomes more designing and because of this the importance of project management is growing. Foreign scientific articles presented the claim that the importance and interest in project management is growing due to the crisis. In case of Slovak respondents there was an interesting situation. Although the theory describes growing interest in given concept, the results of our survey suggest the exact opposite. Currently we can observe a $2.60 \%$ decrease of use when compared to the previous period - see graph 3. Although the analysis determined a decrease in project solution rate, actually this is a negligible value, because only 2 companies represent the decrease in our case. 


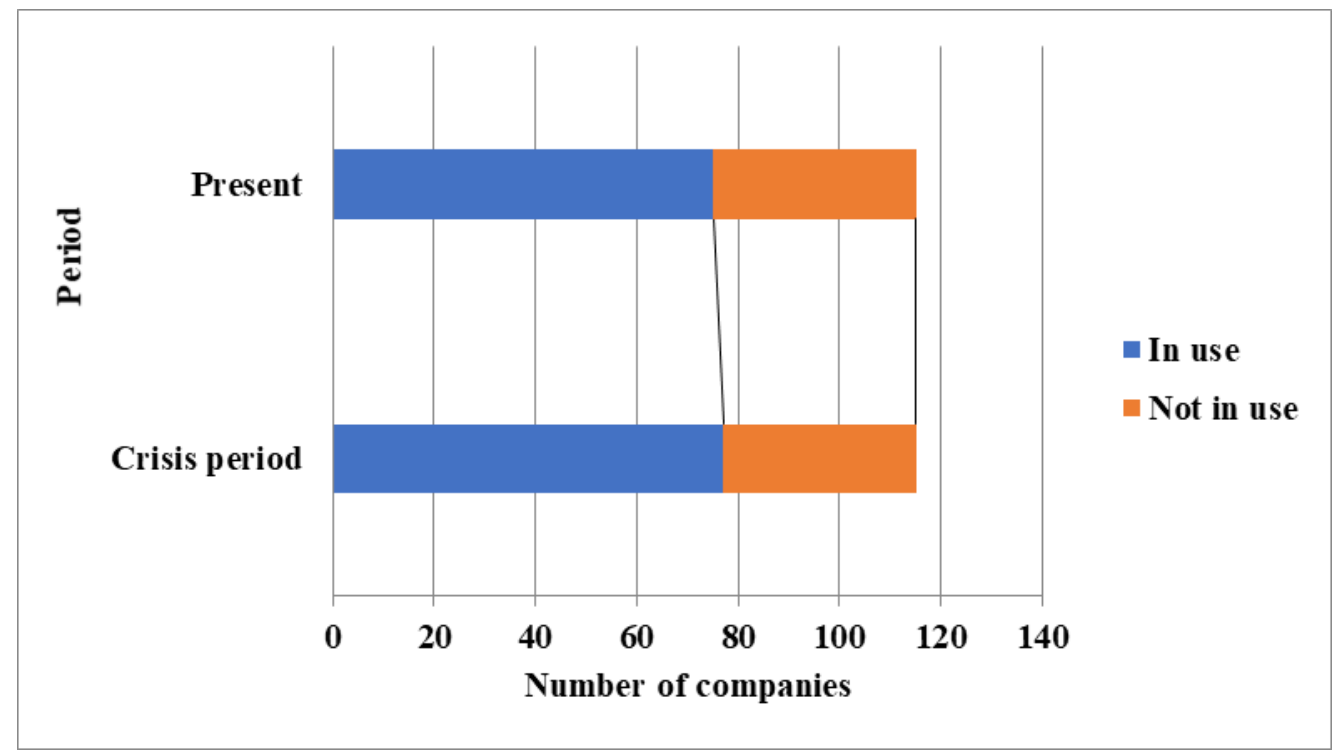

Fig. 3. Interest in project management during crisis and present Source: Own results

The companies have more negative experience with the economic crisis than positive. Many companies found themselves in an unfavourable situation and in an effort to maintain or increase competitiveness, they began to create strategic partnerships more intensively. Companies in Slovakia do not incline to this "trend". About $60 \%$ of the respondents in our survey confirmed that during the crisis they were not part of any strategic partnership and that only $4 \%$ of companies cooperated with other subjects. (see table 1) An interesting finding is that these companies have not experienced any impact of the crisis on their business activity. As a result, we postulate that the primary reason for creating these partnerships was not the impact of the economic crisis.

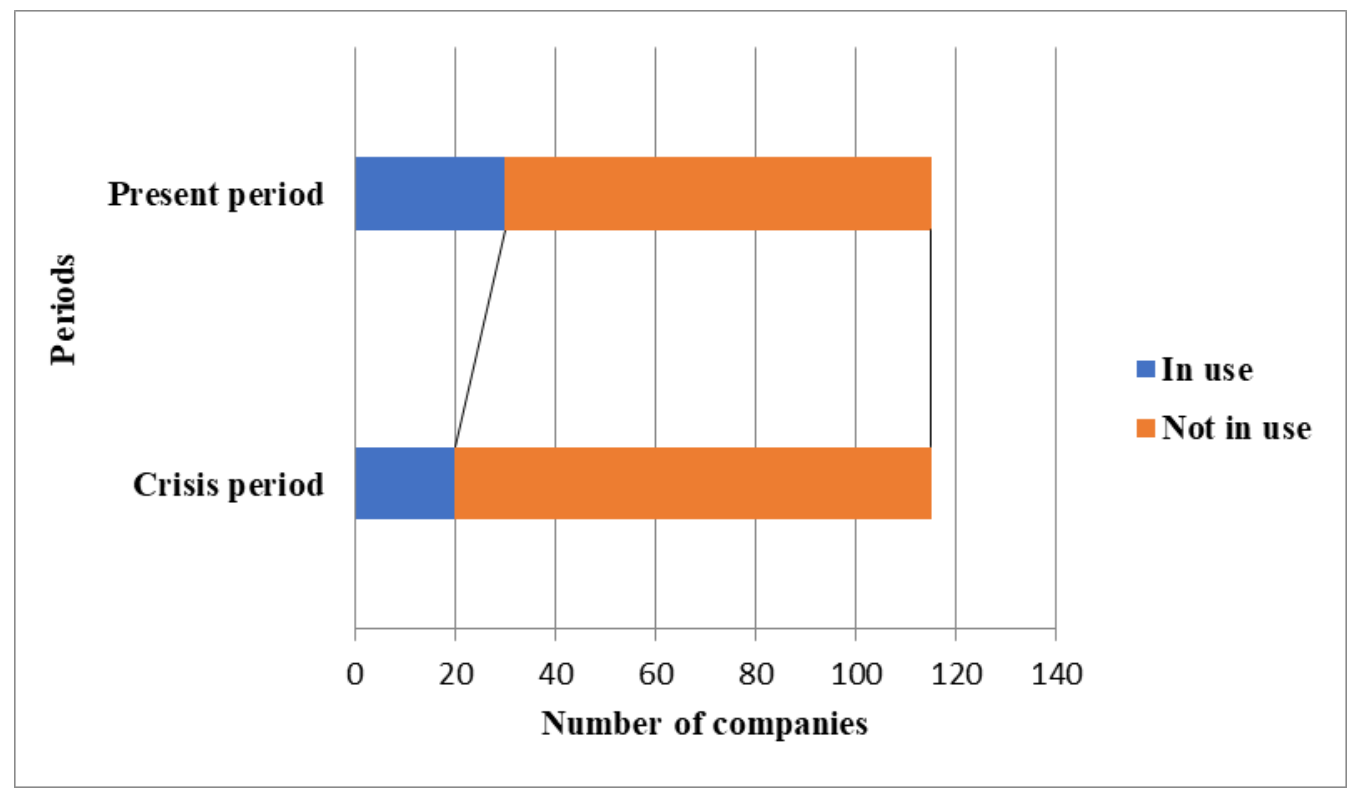

Fig. 4: Interest in strategic partnerships during crisis and present Source: Own results 
Currently, we are seeing an increased number of companies (by about 33\%) over the crisis period that cooperate with other companies on achieving their business goal(s) (see Figure 4). Respondents who work in partnerships created after the economic crisis are mainly businesses that characterized the impact of the crisis as negative. In this case we can deduct that the creation of "post-crisis cooperation" was conditioned by a fading situation in the market due to the crisis. We wanted to statistically verify this claim. Our procedure was as follows:

In table 4 and 5 we compare two classification characters $\mathrm{A}$ and $\mathrm{B}$, where:

- $\quad a_{1}, a_{2}$ are monitored periods, in our case the crisis period and the present,

- $b_{1}, b_{2}, b_{3}$ and $b_{4}$ are rating levels, where 1 - totally disagree, 2 - partly disagree, 3 - partly agree, 4 totally agree.

Table 4. Real multiplicity

\begin{tabular}{|c|c|c|c|c|c|}
\hline Oij & $\mathbf{b}_{1}$ & $\mathbf{b}_{2}$ & $\mathbf{b}_{3}$ & $\mathbf{b}_{4}$ & $\sum$ \\
\hline $\mathbf{a} 1$ & 6 & 8 & 13 & 3 & 30 \\
\hline $\mathbf{a} 2$ & 63 & 18 & 2 & 2 & 85 \\
\hline$\sum$ & 69 & 26 & 15 & 5 & 115 \\
\hline
\end{tabular}

Source: Own results

When calculating theoretical rates (see table 5), in three cases the conditions for continuing the calculation of statistical dependence or independence were not met. Because of this reason we were not able to continue and we can only state that the growing interest in creating various types of strategic partnerships is conditioned by the creation and course of the economic crisis.

Table 5. Theoretical rate

\begin{tabular}{cccccc}
\hline Eij & $\mathbf{b}_{\mathbf{1}}$ & $\mathbf{b}_{\mathbf{2}}$ & $\mathbf{b}_{\mathbf{3}}$ & $\mathbf{b}_{\mathbf{4}}$ & $\sum$ \\
\hline $\mathbf{a} 1$ & 18,00 & 6,78 & 3,91 & 1,30 & 30 \\
\hline $\mathbf{a} 2$ & 51,00 & 19,22 & 11,09 & 3,70 & 85 \\
\hline$\sum$ & 69,00 & 26,00 & 15,00 & 5,00 & 115 \\
\hline
\end{tabular}

Source: Own results

As a result of personnel effect conditioned by the crisis, the organizational area has seen changes in organizational structures. These were naturally optimized and slimmed due to letting go of work forces. The purpose of our finding was to find out the average number of subordinates per 1 manager and the average number of management levels. There was no significant change in the number of subordinates. Currently, a manager has 1 worker less than during the crisis period. The decrease can also be observed in the number of management levels, when companies now operate with a smaller number of management levels. The average respondent included in the questionnaire has 3 management levels and the supervisor supervises and monitors the work of 14 workers, see the Table 6 below.

Table 6. Number of subordinates and number of management level

\begin{tabular}{|c|c|c|c|c|}
\hline \multirow{2}{*}{} & \multicolumn{2}{|c|}{ Pre-crisis period } & \multicolumn{2}{c|}{ Present } \\
\cline { 2 - 5 } & $\begin{array}{c}\text { Number of } \\
\text { subordinates }\end{array}$ & $\begin{array}{c}\text { Number of } \\
\text { management level }\end{array}$ & $\begin{array}{c}\text { Number of } \\
\text { subordinates }\end{array}$ & $\begin{array}{c}\text { Number of } \\
\text { management level }\end{array}$ \\
\hline$\varnothing$ & 15 & 4 & 14 & 3 \\
\hline
\end{tabular}

Source: Own results 
The International Journal

ENTREPRENEURSHIP AND SUSTAINABILITY ISSUES

ISSN 2345-0282 (online) http://jssidoi.org/jesi/

2018 Volume 5 Number 3 (March)

http://doi.org/10.9770/jesi.2018.5.3(18)

According to theoretical source the crisis had an impact on the level of decentralization of decision-making powers at lower levels of management. The dominating answer in the questionnaire results of all monitored organizations is that the impact of the crisis has not been reflected in the delegation of competences to lower levels, nor in centralizing the power to higher levels. Aside from the previous finding, from the results it can be noticed that centralized companies are dominating among the respondents, i.e. higher management levels decide on most issues related to insuring the operation of the business. A slight increase of concentration of competences to higher management levels was especially in finances, marketing, and purchase. It is a natural mechanism when during the crisis companies began to save more and monitor their investments more closely. 6 companies confirmed that due to the economic crisis the human resources area, i.e. for example controlling the extent of meeting the employees' goals is exclusively in the competence of top management. The most significant transfer of decision-making powers was in the area of supply and purchase, i.e. top management delegates' part of its competences to lower organizational units. More detailed results are presented in Figure 5.

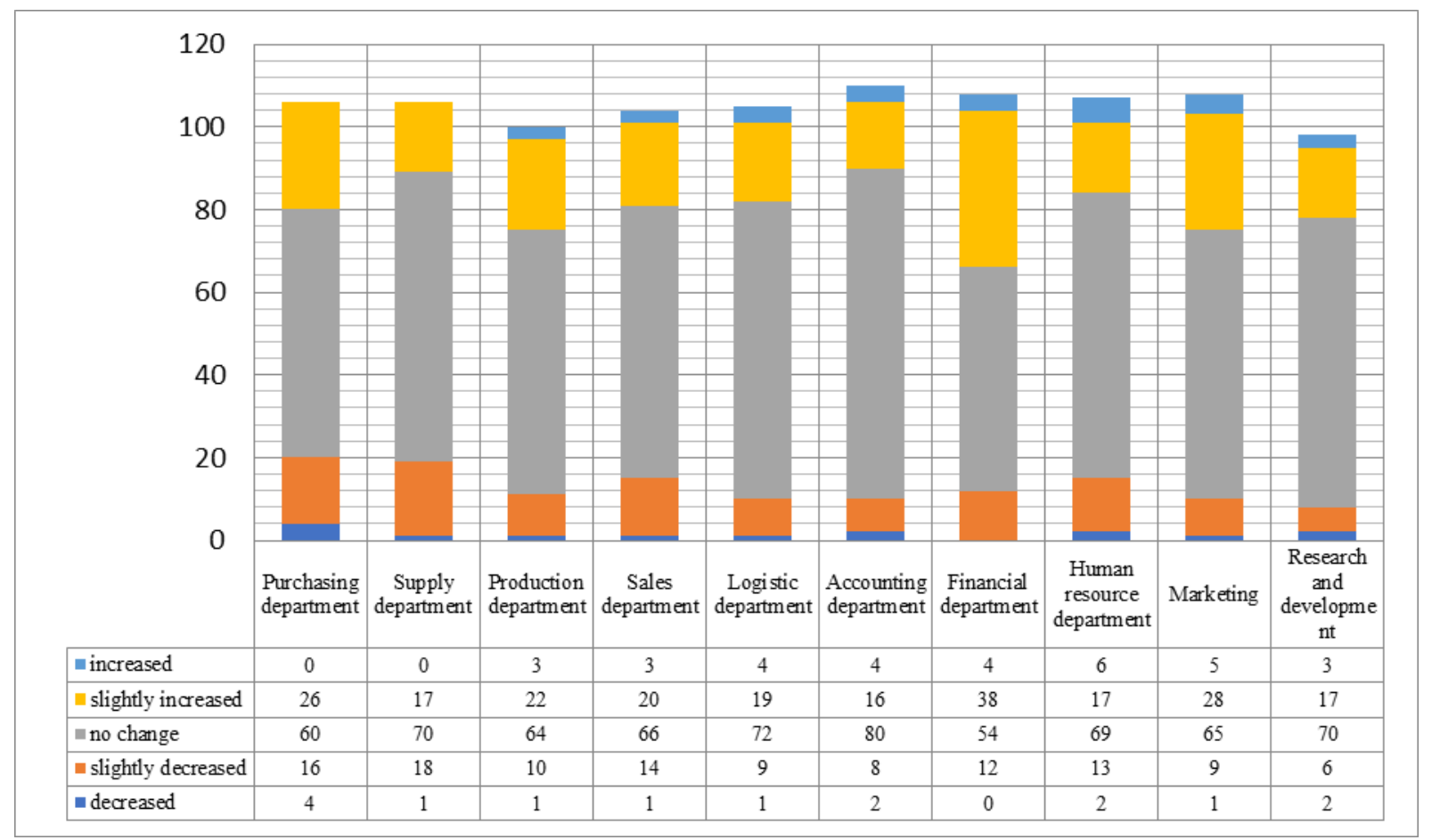

Fig. 5. Changes in centralization of authority caused by crisis Source: Own results

Companies have expressed a negative impact of the crisis on the organization function. Closer analysis revealed that these are business companies, whose economic development was adversely affected by the crisis, i.e. during the pre-crisis period, majority of the companies were predominantly growing, during the crisis the companies were growing, but also stagnating, and currently they are showing signs of stagnation. Of all the concepts analysed above, only project management has been used and only during the post-crisis period. The number of management levels was reduced by 1 , whereby in one case we have recorded a decrease by 2 levels. A more dramatic change happened in the number of subordinates per 1 supervisor. In some companies there is almost a half-drop in the number of workers compared to the period of decline. The degree of centralization was reflected by "increase or slight increase" in all departments they have. 


\section{Results and discussions}

The content of management functions is constantly evolving and responding to the changing environmental conditions. The global economic crisis is definitely one of these conditions. It is a milestone - the sudden interruption of the way the company used to operate. The ability of an entrepreneur to survive a period of economic crisis is mainly in a quick response to a changing business environment and take advantage of the situation as an opportunity for company success.

During the economic crisis companies reduced any unnecessary costs such as surplus stocks, surplus production or various manufacturing deficiencies, reduced quality, possible complaints. For these and other reasons, businesses tended to optimize, rationalize and reduce excessive processes and activities, to eliminate everything that did not bring value to businesses in order to streamline processes and reduce costs to the minimum level. According to a number of experts (Burton - Boeder, 2003) (Charron et all, 2015) (Košturiak, 2012) (Georgescu, 2011), the era of global slimming has begun. In a more detailed analysis, we found that the intensity of eliminating excess processes and activities is affected by the economic crisis. Statistical contingency has been demonstrated. Actually, the number of companies with lean management increased by $6.67 \%$ in comparison with crisis period.

According to some economists, the increase of project management importance led to the change in the organization that becomes more designing. Based on the development of tools, the project management has become crucial in achieving business goals. The primary reason for the projects development was the response to a complex business environment and the need to respond to new situations and problems that arose as a result of the economic crisis. Project management implementation discovered many advantages - motivation and engagement of employees, building a project team, strengthening the team spirit, etc. Despite of the abovementioned benefits of the concept, we are currently following a $2.60 \%$ drop in usage over the previous period. This is above all a minimal decline, although respondents are aware of the benefits of project management approach implementation. Theoretical sources inform that more than $65 \%$ of respondents currently use the project management in their organizations. Over the last 50 years business practice has shown itself as project management approach brings concrete results to the business. World Project Managers clearly express the increasing tendency of project management approach. Given the post-crisis business environment, pressure on efficiency, performance, cost reduction, quality improvement and risk reduction many more companies will be project-based and not process-driven. (Minárik, 2016).

Enterprises, in an attempt to survive the crisis with minimal consequences, they have been more focused on creating different strategic partnerships. Our results show a growing interest in partnership/membership with other businesses to achieve a common business goal. We have not been able to confirm statistically the increased interest in strategic cooperation, so we can only say that the growing interest in partnerships creation was conditioned by crisis. Currently 30/115 enterprises collaborate with other companies.

Organizational structures have been naturally slimmed up and optimized in times of crisis due to the dismissal, resulting in managerial level reduction. Based on our analysis, we found that companies currently have (on average) 3 levels of management, which represents a 1-point decrease in comparison with the crisis period. Optimizing the organizational structure is an appropriate tool to increase the efficiency of business operations. Our research sample consists predominantly of a centralized type of organizational structures where higher managerial level decides about the majority of all the issues related to ensuring the business operation. 
The International Journal

ENTREPRENEURSHIP AND SUSTAINABILITY ISSUES

ISSN 2345-0282 (online) http://jssidoi.org/jesi/

2018 Volume 5 Number 3 (March)

http://doi.org/10.9770/jesi.2018.5.3(18)

\section{Conclusions}

In our paper, we have presented research results on the impact of the economic crisis on the function of organization in company. We state that the crisis had a significant impact on organization methods used by companies.

We have discovered significant dependence between the crisis and the post-crisis period in using lean management. Our study confirmed that currently more than a half of respondents use the concept of lean management and compared to the crisis period we observed a 6,67\% increase. By using Pearson's correlation coefficient, we found a moderated dependence between the analysed periods (crisis and post-crisis) and the degree of using lean management.

We state that growing interest in creating various types of strategic partnership is conditioned by the creation and the course of the economic crisis. Companies confirmed more negative experiences than positive with crisis. In effort to maintain or to increase competitiveness, companies started to create more intensively strategic partnership. The increase was by about $33 \%$.

Another concept we were interested in our research was project management. Currently we can observe a slight decrease $(2,6 \%)$ in use of the concept in comparison with crisis period. As a result of personnel effect conditioned by the crisis, we discovered the changes in span of management - from 15 subordinates in pre-crisis period to 14 subordinates nowadays. We have discovered the decrease in the number of management levels - from 4 in precrisis period to 3 in post-crisis period.

The impact of the crisis has not been reflected in the delegation of competences to lower levels, nor in centralizing the power to higher levels for the majority of our respondents. A slight increase of concentration of competencies to higher management levels was especially in finance, marketing, and purchase. The results of our research are both interesting and practical. It opens novel questions about deeper causations of our results that should be explained by using further research.

\section{References}

Abrham, J.; Bilan, Y.; Krauchenia, A.; Strielkowski, W. 2015 Planning horizon in labour supply of Belarusian small entrepreneurs. Economic Research-Ekonomska Istrazivanja 28(1): 773-787. http://doi.org/10.1080/1331677x.2015.1084238

Beňová, M., \& Szabo, L. 2016. Clusters - modern forms of doing business. In: Aktuálne problémy podnikovej sféry. Bratislava: Ekonóm. pp. 43-49.

Burton, T.; Boeder, S. 2003. The lean extended enterprise. J. Ross Publishing; Florida.

Charron R.; Harrington H. J.; Voehl F.; Wiggin H. 2015. The Lean Management Systems Handbook. Productivity Press Book, Taylor and Francis Group: Boca Raton, London.

Č́belková, I.; Abrhám, J.; Strielkowski, W. 2015a. Factors influencing job satisfaction in post-transition economies: the case of the Czech Republic. International Journal of Occupational Safety and Ergonomics 21(4): 448-456. http://doi.org/10.1080/10803548.2015.1073007

Č́belková, I.; Strielkowski, W.; Mirvald, M. 2015b. Business influence on the mass media: a case study of 21 countries. Transformation in Business \& Economics 14(1): 65-75

Dekier, L. 2012. The Origins and Evolution of Lean Management System, Journal of International Studies 5(2): 46-51. http://www.jois.eu/files/DekierV_5_N1.pdf 
Georgescu, D. D. 2011. Lean Thinking and Transferring Lean Management - The Best Defence against an Economic Recession? European Journal of Interdisciplinary Studies 1(3):4-20

Grant, R. M. 2008. The Future of Management: Where is Gary Hamel Leading Us? In Long Range. Planning. Available on the Internet: http://citeseerx.ist.psu.edu/viewdoc/download?doi=10.1.1.455.1135\&rep=rep1\&type=pdf

Hamel, G. 2006. The why, what, and how of management innovation, Harvard Business Review 84(2): 1-15.

Holagh, S. R.; Noubar, H. B. K.; Bahador, B. V. 2014. The effect of organizational structure on organizational creativity and commitment within the Iranian municipalities, Procedia - Social and Behavioral Sciences 156(11): 213-215. http://doi.org/10.1016/j.sbspro.2014.11.175

Janda, K.; Rausser, G.; Strielkowski, W. 2013. Determinants of Profitability of Polish Rural Micro-Enterprises at the Time of EU Accession, Eastern European Countryside 19: 177-217. https://doi.org/10.2478/eec-2013-0009.

Jirsák, P.; Holman, D. 2012. Productivity of Lean Logistics System. System Logistics \& Sustainable Transport 3(1): 30-40.

Kastelle, T. 2013. Hierarchy is overrated, Harvard Business Review. Available from the Internet: https://hbr.org/2013/11/hierarchy-isoverrated

Košturiak, J. 2012. Štíhly podnik. Available from the Internet: http://www.ipaslovakia.sk/sk/ipa-slovnik/stihly-podnik

Košturiak, J. 2017. Strategické plánovanie. Available from the Internet: http://www.ipaslovakia.sk/sk/ipa-slovnik/strategicke-planovaniestrategy-deployment

Krejcí, M.; Strielkowski, W.; Čabelková, I. 2015. Factors that influence the success of small and medium enterprises in ICT: a case study from the Czech Republic, Business: Theory and Practice 16: 304-315. https://doi.org/10.3846/btp.2015.521

Lo Nigro, G.; Bruccoleri, M.; Perrone, G. 2006. Negotiation in distributed production planning environment, International Journal od Production Research, 44(8): 3743-3758.

Minárik, P. 2016. Nefungujúce projekty a projektový manažment [Non-functioning projects and project management]. In Zisk. Available from the Internet: https://www.slideshare.net/COMM-PASS/commpass-672015preco-projekty-nefunguju

Mišún, J.; Mišúnová-Hudáková, I. 2017. Kontrolovanie v manažmente [Control in management]. Bratislava: Kartprint.

Monni, S.; Palumbo, F.; Tvaronavičienė, M. 2017. Cluster performance: an attempt to evaluate the Lithuanian case, Entrepreneurship and Sustainability Issues 5(1): 43-57. http://doi.org/10.9770/jesi.2017.5.1(4)

Pamfilie, R.; Petcu, A.; Draghici, M. 2012. The importance of leadership in driving a strategic Lean Six Sigma management, Procedia Social and Behavioral Sciences. 58(10): 187-196. https://doi.org/10.1016/j.sbspro.2012.09.992

Pinto, K. J.; Winch, G. 2016. The unsettling of „settled science“: The past and future of the management of projects. International Journal of Project Management 34(2): 237-245. http://doi.org/10.1016/j.ijproman.2015.07.011

Razminiené, K.; Tvaronavičienė, M. 2017. Economic globalization and its impacts on clustering, Terra Economicus 15 (2): 109-121 https://doi.org/10.23683/2073-6606-2017-15-2-109-121

Qi, Y.; Tang, M.; Zhang, M. 2014. Mass Customization in Flat Organization: The Mediating Role of Supply Chain Planning and Corporation Coordination, Journal of Applied Research and Technology 12(2): 171-181. http://doi.org/10.1016/S1665-6423(14)72333-8

Sabic-Lipovaca, A.; Strielkowski, W.; Bilan, Y. 2016. Intertemporal substitution and labour supply of Bosnian SME's, Amfiteatru Economic 18(43): 634-653.

Simionescu, M.; Ciuiu, D.; Bilan, Y.; Strielkowski, W. 2016. GDP and Net Migration in Some Eastern and South-Eastern Countries of Europe. A Panel Data and Bayesian Approach, Montenegrin Journal of Economics 12(2): 161-175. http://doi.org/10.14254/1800$\underline{5845.2016 / 12-1 / 10}$ 
The International Journal

ENTREPRENEURSHIP AND SUSTAINABILITY ISSUES

ISSN 2345-0282 (online) http://jssidoi.org/jesi/

2018 Volume 5 Number 3 (March)

http://doi.org/10.9770/jesi.2018.5.3(18)

So, S.; Sun, H. 2015. Lean thinking as organisational practice in enabling supply chain sustainability. International Journal of Environmental Technology and Management 18(4): 291-308.

Tarišková, N. 2015. Perspektívy kvalitatívnych ukazovatel'ov v modeloch merania výkonnosti podniku: Perspectives of qualitative indicators in business performance management systems. Flexibilita pracovnej sily ako záruka istoty pre pracovníka a organizáciu v kontexte Lisabonskej stratégie 2020 a stratégie Európa 2020. Bratislava: Ekonóm.

Tenera, A.; Pinto, L. C. 2014. A Lean Six Sigma (LSS) Project Management Improvement Model. In Procedia - Social and Behavioral Sciences, 119(3), 912-920. http://doi.org/10.1016/j.sbspro.2014.03.102

Trend. 2016. Lean manažment. Available from the Internet: http://konferencie.etrend.sk/trend_konferencie/lean-manazment-2016.html

Vilkas, M.; Koreckaja, I..; Katiliūtè, E.; Bagdonienė, D. 2015. Adoption of Lean Production: Preliminary Evience from Lithuania, Procedia - Social and Behavioral Sciences 213(6): 884-889. http://doi.org/10.1016/j.sbspro.2015.11.500

Zagorsek, B.; Hlavova, N.; Bolek, V. 2017. The Current Role of Project Management in Competitiveness of Companies, Actual Problems of Economics 191(5):99-106.

Záležaková, E. 2012. Podniky vkrize: nutnost' nového ponimania manažérskych funkcií [Businesses in crisis: the need to redefine managerial functions]. Available from the Internet: http://www.hrvpraxi.sk/33/podniky-v-krizenutnost-noveho-ponimania-

manazerskychfunkciiuniqueiduchxzASYZNatvABpzW7TbbuYGq1Cy917/?query=z\%E1le\%BE\%E1kov\%E1\&serp=1

\section{Aknowledgements}

This research was supported by the project „The innovative approaches to management and their influence on the competitiveness and the successfulness of the companies within the conditions of the global economy. ", VEGA No.: 1/0109/17 - a project funded by the University of Economics in Bratislava and led by doc. Ing. Nadežda Jankelová, Ph.D.

Short biographical note about the contributors at the end of the article (name, surname, academic title and scientific degree, duties, research interests):

Nadežda JANKELOVÁ is a Professor at the University of Economics, Slovakia. She works on the topics of innovation, competitiveness and success of companies comprised by small and large enterprises. Research interests: entrepreneurship; small business; competitiveness; global economy.

Andrea JANKUROVÁ is an Assistant Professor at the Danubius University, Sládkovičovo, Slovakia. Her research interests include leadership, human resource management, factors of enterprise success, small business economics, and innovation and competitiveness.

Martina BEŇOVÁ is a Ph.D. student at the University of Economics, Slovakia. Research interests: entrepreneurship; small business; competitiveness; small and medium enterprises.

Zuzana SKORKOVÁ is a Ph.D. student at the University of Economics, Slovakia. Research interests: entrepreneurship; competitiveness; small and medium enterprises; innovations, modern management.

Copyright (C) 2018 by author(s) and VsI Entrepreneurship and Sustainability Center

This work is licensed under the Creative Commons Attribution International License (CC BY). http://creativecommons.org/licenses/by/4.0/

(c) (i) Open Access 